\title{
Analisis Vegetasi, Estimasi Biomassa dan Stok Karbon Ekosistem Mangrove Pesisir Kecamatan Latambaga, Kabupaten Kolaka
}

\section{Analysis on Vegetation, Biomass and Carbon Stock Estimation of Mangrove Ecosystem in Coastal Line of Latambaga District, Kolaka Regency}

\author{
La Ode Abdul Fajar Hasidu ${ }^{1 *}$, Arif Prasetya ${ }^{2}$, Maharani $^{1}$, Asni $^{2}$, Agusriyadin $^{3}$, Azhar Aras Mubarak $^{4}$, \\ Akhmad Fadli Ibrahim ${ }^{5}$, Sudarwin Kamur ${ }^{6}$, dan Gaby Nanda Kharisma ${ }^{6}$ \\ ${ }^{1 *}$ Jurusan Ilmu Kelautan, Universitas Sembilanbelas November Kolaka, Kampus B, Jl. Jend. Sudirman, \\ Buton Tengah-Indonesia. 93762 \\ ${ }^{2}$ Jurusan Ilmu Perikanan, Universitas Sembilanbelas November Kolaka, Kampus B, Jl. Jend. Sudirman, \\ Buton Tengah- Indonesia. 93762 \\ ${ }^{3}$ Jurusan Kimia, Universitas Sembilanbelas November Kolaka, jl. Pemuda, Kolaka- Indonesia. 93511. \\ ${ }^{4}$ Jurusan Teknik Perkapalan,Universitas Sembilanbelas November Kolaka, Kampus B, Jl. Jend. Sudirman, \\ Buton Tengah- Indonesia. 93762 \\ ${ }^{5}$ Jurusan Teknik Mesin,Universitas Sembilanbelas November Kolaka, Kampus B, Jl. Jend. Sudirman, \\ Buton Tengah- Indonesia. 93762 \\ ${ }^{6}$ Jurusan Pendidikan Geografi, Universitas Sembilanbelas November Kolaka, jl. Pemuda, Kolaka- Indonesia. 93511.
}

Corresponding author*) : fajarhasidu90@gmail.com

\begin{abstract}
Study of vegetation analysis, biomass estimation and carbon stock of mangrove ecosystem are important to determine the ecosystem condition as well as the ability of mangrove ecosystem to absorb and store carbon into their biomass. The aims of study was to know the condition of mangrove vegetation, percentage of coverage, above ground biomass $(A G B)$, as well as blue carbon stock potential of magrove vegetation in the coastal line of Latambaga District, Kolaka Regency. This study was conducted in August, 2019. The study used kuadran transect method to measure the vegetation and then compared it with hemispherichal photography method. This method was used to calculate the percentage of mangrove coverage based on pixel separation between sky pixel and vegetation pixel. The $A G B$ data was calculated by steam diameter data (Diameter at Breast High/DBH) and allometric equation on each species. The carbon stock data was calculated by the $\mathrm{C}$ constanta from organic matter, and $A G B$ data. The result showed that the highest mangrove density respectively were in station II $\left(5299,99 \mathrm{ind} / \mathrm{ha}^{2}\right)$, station I $\left(3466,66 \mathrm{ind} / \mathrm{ha}^{2}\right)$, and station III $\left(3066,66 \mathrm{ind} / \mathrm{ha}^{2}\right)$. The percentage of mangrove coverage based on canopy pixel shows the same figure with mangrove density where the highest percentage of mangrove coverage was in station II $(84,0716 \%)$, station I $(81,5368 \%)$, and statiton III $(80,9978 \%)$ respectively. The mangroves ecosystem in this location was in the good condition with a high density and high percentage of mangrove coverage. The composition of mangrove vegetation in this location was dominated by Rhizophora apiculata and Rhizophora mucronata with the weaning $(\mathrm{DBH}<10 \mathrm{~cm})$ and pole $(\mathrm{DBH}<20 \mathrm{~cm})$ category. Although on the good condition, mangroves ecosystem in the coastal line of Latambaga district still has a threat of land use change such as pond. The highest of $A G B$ was in station 1 (226,76 ton/ha), followed by station 3 $(181,47 \mathrm{ton} / \mathrm{ha})$, and station 2 (76,06 ton/ha) respectively. Blue carbon stock was directly proportional to the $A G B$ data. The highest total of blue carbon stock was in station $1(106,57$ ton/ha), followed by station 3 (85,29 ton/ha), and station $2(35,75$ ton/ha) respectively.
\end{abstract}


Keywords: Mangroves, vegetation, AGB, carbon stock

\begin{abstract}
ABSTRAK
Studi analisis vegetasi, estimasi biomasa dan stok karbon ekosistem mangrove sangat penting dilakukan untuk menentukan kondisi ekosistem dan kemampuan ekosistem mangrove dalam menyerap karbon dan menyimpannya ke dalam biomassanya. Tujuan dari penelitian ini adalah untuk mengetahui kondisi vegetasi mangrove, persentase tutupan vegetasi, status biomassa permukaan $(A G B)$, serta potensi stok karbon yang tersimpan di vegetasi mangrove di pesisir Kecamatan Latambaga, Kabupaten Kolaka. Penelitian ini dilakukan pada bulan Agustus 2019. Metode penelitian menggunakan transek kuadrat untuk menghitung kerapatan mangrove, selanjutnya dibandingkan dengan metode Hemispherichal Photography untuk mengukur persentase penutupan vegetasi mangrove berbasis pemisahan antara pixel langit dan pixel vegetasi. Data $A G B$ dihitung berdasarkan data diameter batang mangrove (Diameter at Breast Heigh/DBH) dan persamaan allometrik dari setiap spesies. Data stok karbon dihitung dengan menggunakan konstanta karbon dari bahan organik dan data biomassa $(A G B)$. Hasil penelitian menunjukkan, kerapatan mangrove tertinggi secara berturut-turut terdapat di stasiun $2\left(5299,99 \mathrm{ind} / \mathrm{ha}^{2}\right)$, stasiun 1 (3466,66 ind/ha $\left.{ }^{2}\right)$, dan stasiun $3\left(3066,66 \mathrm{ind} / \mathrm{ha}^{2}\right)$. Persentase tutupan mangrove berbasis pixel kanopi menunjukkan hasil yang sama dengan kerapatan mangrove, dimana persentase tutupan mangrove tertinggi terdapat di stasiun $2(84,0716 \%)$, stasiun 1 $(81,5368 \%)$, dan stasiun 3 (80,9978\%). Ekosistem mangrove yang ada lokasi tersebut dalam kondisi baik dengan kerapatan dan persentase tutupan yang cukup tinggi. Komposisi penyusun vegetasi mangrove yang ada di Kecamatan Latambaga didominasi oleh mangrove jenis Rhizophora apiculata dan Rhizophora mucronata dengan kelas pertumbuhan sapihan (DBH $<10 \mathrm{~cm})$ dan tiang (DBH $<20$ $\mathrm{cm}$ ). Meskipun dalam kondisi yang baik, ekosistem mangrove di pesisir Kecamatan Latambaga mengalami ancaman alih fungsi lahan menjadi tambak. Total $A G B$ tertinggidi stasiun 1 (226,76 ton/ha), diikuti oleh stasiun 3 (181,47 ton/ha), dan stasiun 2 (76,06 ton/ha). Stok karbon berbanding lurus dengan data $A G B$. Total stok karbon tertinggi juga terdapat pada stasiun $1(106,57$ ton/ha), diikuti oleh stasiun 3 (85,29 ton/ha), dan stasiun 2 (35,75 ton/ha).
\end{abstract}

Kata kunci: Mangrove, vegetasi, AGB, stok karbon

DOI: http://dx.doi.org/10.33772/jspi.v5n2.

\section{PENDAHULUAN}

Ekosistem mangrove merupakan ekosistem yang terdapat di wilayah pesisir dengan produktivitas yang tinggi (Aksornkoae, 1993), serta memiliki keanekaragaman fauna akuatik yang cukup tinggi (Murniati \& Pratiwi, 2015). Hutching \& Seanger,(1987) menjelaskan bahwa mangrove merupakan tumbuhan pesisir yang berperan dalam melindungi garis pantai tropis dan subtropis. Mangrove merupakan komunitas tumbuhan di zona pasang surut di pantai tropis yang mampu tumbuh di perairan asin dan payau (Kusmana, 1993; Nybakken, 1992; Jamili, 2019). Mangrove tersebut mampu membentuk sebuah ekosistem di wilayah pesisir yang sangat produktif.

Selain itu, ekosistem mangrove juga memiliki peranan yang sangat penting dalam memitigasi dampak perubahan iklim (Sharma et al., 2019; Indrayani et al., 2021). Analuddin et al., (2020) menyatakan bahwa ekosistem mangrove berperanan penting dalam penyuplai $\mathrm{O}_{2}$, dan mengabsorbsi $\mathrm{CO}_{2}$ dari atmosfer. Lebih lanjut, Alongi \& Mukhopadhyay (2014), menyatakan bahwa ekosistem ini mampu menyerap dan menyimpan banyak karbon.Karbon yang tersimpan di ekosistem mangrove ini tersimpan dalam bentuk biomassa yang dikenal dengan istilah karbon biru. 
62 Hasidu et al.

JURNAL SAINS dan INOVASI PERIKANAN / Journal of Fishery Science and Innovation Vol. 5, No. 2, 60-71, Juli 2021

Karbon biru merujuk kepada karbon yang terserap serta tersimpan di ekosistem pesisir, laut, serta rawa garam. Menurut Kauffman et al., (2014), mangrove memiliki jasa lingkungan dan peranan yang sangat penting sebagai penyerap dan penimbun karbon di atmosfer. Ekosistem ini memiliki potensi sebagai carbon stock yang disimpan dalam bentuk biomassanya, maupun ditimbun di dalam substratnya. Oleh sebab itu, jika eksistensi ekosistem mangrove tersebut mengalami degradasi, maka dapat mempengaruhi fungsi ekosistem mangrove serta mengganggu keseimbangan ekologis yang ada di wilayah pesisir. Untuk mencegah terjadinya degradasi ekosistem mangrove, diperlukan upaya konservasi kawasan ekosistem mangrove.

Ekosistem mangrove yang ada di pesisir Kecamatan Latambaga, Kabupaten Kolaka merupakan ekosistem mangrove yang sudah terdegradasi akibat perubahan penggunaan lahan menjadi tambak dan pemukiman (Hasidu et al., 2020). Selain itu, ketersediaan data dan informasi mengenai kondisi ekosistem mangrove di lokasi tersebut juga sangat sedikit. Data Profil KP3K Provinsi Sulawesi Tenggara tahun 2015,tercatat dua jenis mangrove yang terdapat di Kabupaten Kolaka, dengan tingkatan pertumbuhan semai, anakan dan pohon. Penelitian ini bertujuan untuk mengetahui kondisi vegetasi, persentase tutupan mangrove, status biomassa permukaan $(A G B)$, serta status stok karbon ekosistem mangrove yang ada di Kecamatan Latambaga, Kabupaten Kolaka, sehingga diharapkan dapat menjadi data dasar mengenai status kondisi ekosistem mangrove, dan status biomassa dan stok karbonnya dalam upaya konservasi dan pengelolaan ekosistem mangrove di Kabupaten Kolaka.

\section{METODE PENELITIAN}

Penelitian dilakukan pada bulan Agustus, 2019 di ekosistem mangrove Kecamatan Latambaga, Kabupaten Kolaka, Sulawesi Tenggara. Secara spasial, lokasi penelitian ditampilkan pada Gambar 1.

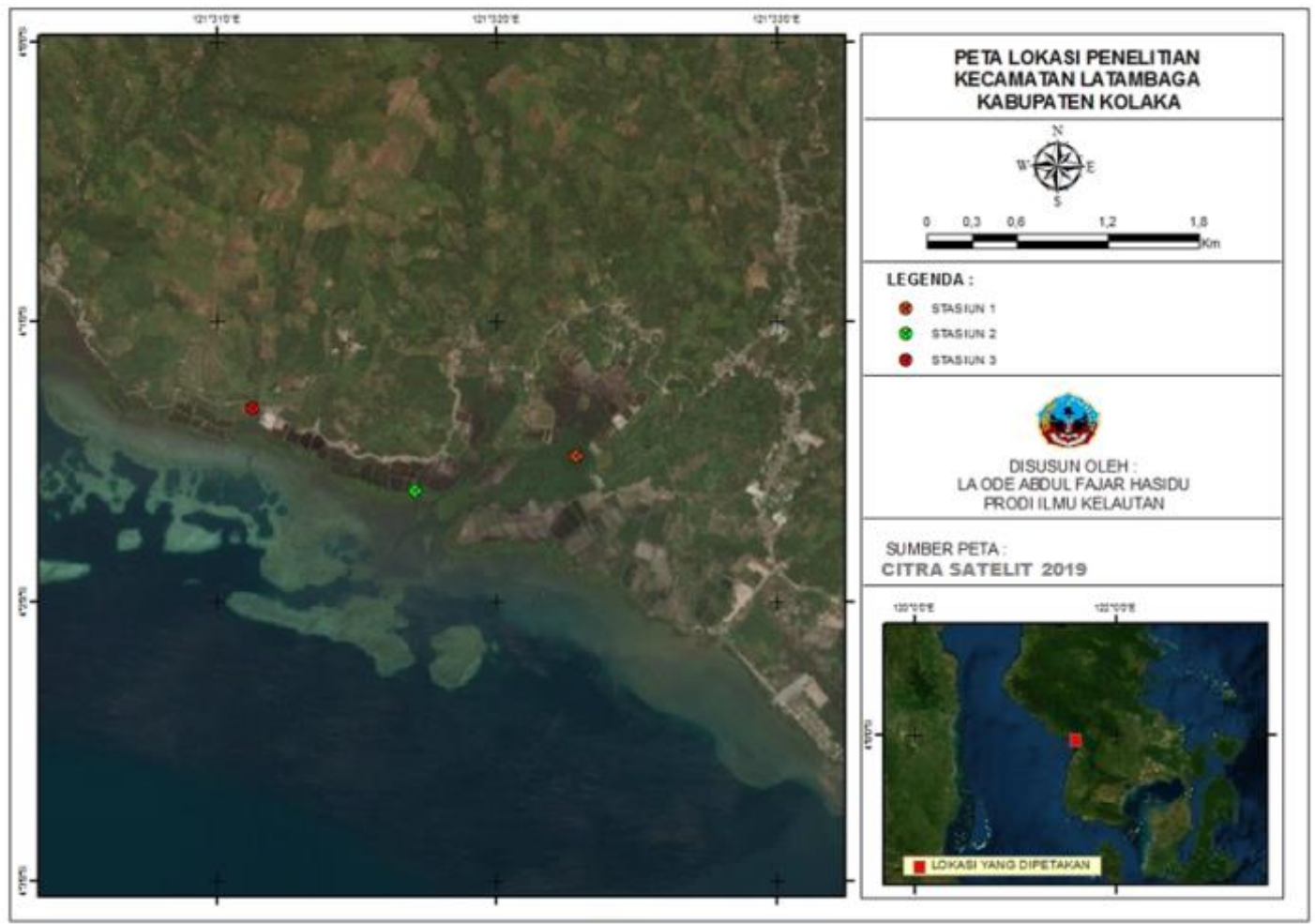

Gambar 1. Peta lokasi penelitian 


\section{a. Sampling dan Analisis Vegetasi}

Pengambilan data vegetasi mangrove menggunakan plot pengamatan ukuran $100 \mathrm{~m}^{2}$ (Jamili et al., 2009; Analuddin et al., 2015). Plot pengamatan diletakkan pada setiap transek $100 \mathrm{~m}$ yang diletakan tegak lurus garis pantai sebagaimana yang diilustrasikan pada Gambar 2. Data yang dikoleksi berupa jenis mangrove, dan ukuran $\mathrm{DBH}$.

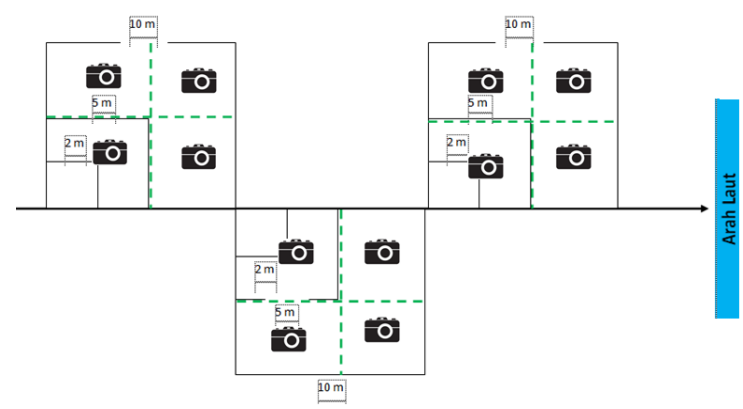

Gambar 2. Skema transek pengambilan data

Data vegetasi mangrove yang terkumpul dianalisis secara kuantitatif. Setiap parameter kuantitatif dari data yang diperoleh dianalisis untuk menentukan densitas, frekuensi dominansi, dan indeks nilai penting sebagai berikut

$K=\frac{\text { Jumlahsuatujenis }}{\text { Luasarealplot }}$

$K R=\frac{\text { Ksuatujenis }}{\text { Ktotalseluruhjenis }} \times 100 \%$

$F=\frac{\text { Jumlahplotsuatujenisterdapat }}{\text { totalseluruhplotpengamatan }}$

$F R=\frac{F \text { suatujenis }}{\text { Ftotalseluruhjenis }} \times 100 \%$

$D=\frac{\text { BAsuatujenis }}{\text { luasarealsampel }}$

$B A=\left(\frac{d}{2}\right)^{2} \times 3,14$

$D R=\frac{\text { Dsuatujenis }}{\text { Dtotalseluruhjenis }} \times 100 \%$

$I N P=K R+F R+D R$
Keterangan: K (Kerapatan); KR (Kerapatan Relatif); F (Frekuensi); FR (Frekuensi Relatif); D (Dominansi); DR (Dominansi Relatif); BA (Basal Area); INP (Indeks Nilai Penting).

b. Analisis Tutupan Vegetasi dengan Hemisperichal Photography

Penentuan persentase penutupan vegetasi mangrove menggunakan metode Hemisperichal Photography yang mengacu kepada Dharmawan \& Pramudji (2017) berikut:

1. Setiap plot ukuran $10 \mathrm{~m} \times 10 \mathrm{~m}$ dibagi menjadi 4 bagian $(5 \mathrm{~m} \times 5 \mathrm{~m})$ untuk pengambilan gambar vegetasi

2. Gambar tutupan vegetasi diambil tegak lurus setinggi dada menggunakan kamera standar minimum 12 Megapixel (MP) dan lensa fish eye untuk memperluas bidang pandang.

3. Hasil gambar dianalisis menggunakan software imageJ untuk menghitung perbandingan jumlah pixel langit dan pixel vegetasi

4. Data hasil analisis dibandingkan dengan metode analisis vegetasi. Penentuan status kondisi ekosistem mangrove berdasarkan Keputusan Menteri Lingkungan Hidup (Kepmen-LH) No. 201 tahun 2004.

\section{c. Analisis Biomassa Permukaan (AGB)}

Data vegetasi mangrove berupa ukuran DBH digunakan untuk menganalisis biomassa permukaan mangrove $(A G B)$, menggunakan persamaan allometrik yang telah dikembangkan dari setiap spesies yang ditemukan. Persamaan allometrik spesies untuk semua spesies yang diperoleh ditunjukkan pada Table 1.

Tabel 1. Persamaan allometrik mangrove

\begin{tabular}{lll}
\multicolumn{1}{c}{ Spesies } & \multicolumn{1}{c}{$\begin{array}{c}\text { Persamaan } \\
\text { allometrik }\end{array}$} & Referensi \\
\hline R. apiculata & $\begin{array}{l}\text { Wtop }=0.268 D B H^{2.345} \\
R^{2}=0,93, n=8\end{array}$ & \\
& Wtop $=0.143 D B H^{2.519}$ & $\begin{array}{l}\text { Analuddin et } \\
\text { R. } \text { mucronata }\end{array}$ \\
& $R^{2}=0,97, n=8$ & \\
C. tagal & Wtop $=0.529 D B H^{2.04}$ & \\
& $R^{2}=0.96, n=8$ & \\
Soneratia spp. & $W=0,258 D B H^{2.287}$ & Kusmana et \\
& $R^{2}=0,91, n=30$ & al., 2018 \\
B. gymnorrhiza & Wtop $=0.186 D B H^{2.31} R 2=$ & Clough and \\
& $0.99, n=17$ & Scott, 1989 \\
\hline
\end{tabular}


64 Hasidu et al.

JURNAL SAINS dan INOVASI PERIKANAN / Journal of Fishery Science and Innovation

Vol. 5, No. 2, 60-71, Juli 2021

\section{d. Analisis Stok Karbon}

Estimasi stok karbon ekosistem mangrove yaitu dengan mengalikan nilai konstanta karbon dari bahan organik $(0,47)$ dengan biomassa mangrove yang diperoleh. Metode estimasi stok karbon tersebut mengacu kepada metode IPCC 2008 dalam Analuddin et al., (2020) berikut:

Stokkarbon $=0,47$ xbiomassa

\section{HASIL DAN PEMBAHASAN}

\section{Hasil}

\section{a. Struktur Vegetasi Mangrove}

Hasil analisis struktur vegetasi mangrove di ekosistem mangrove Kecamatan Latambaga menunjukkan ukuran diameter batang yang berbeda di setiap stasiunnya. Kelas ukuran DBH ditunjukkan pada Gambar 2.

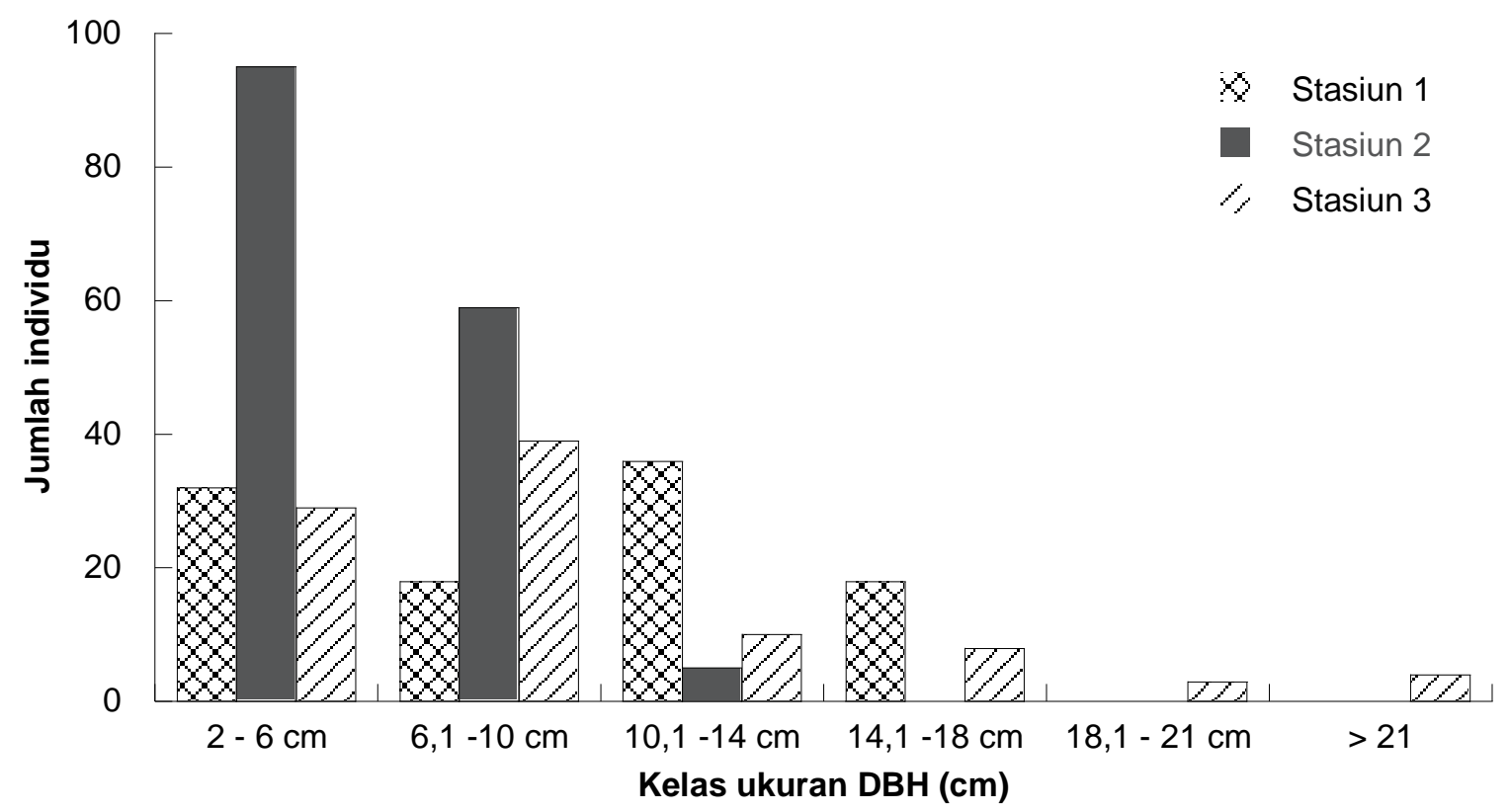

Gambar 2. Struktur vegetasi berdasarkan kelas ukuran DBH

Tabel 2. Struktur vegetasi ekosistem mangrove di Kecamatan Latambaga

\begin{tabular}{|c|c|c|c|c|c|c|c|c|c|}
\hline St & $\begin{array}{c}\text { Tingkatan } \\
\text { Vegetasi }\end{array}$ & No & Nama Spesies & $\sum_{\text {ind }}$ & K (ind/ha) & KR (\%) & $\operatorname{FR}(\%)$ & DR & INP (\%) \\
\hline \multirow{8}{*}{$\mathbf{I}$} & \multirow{4}{*}{ Sapihan } & 1 & $R$.apiculata & 26 & 866,66 & 52 & 37,50 & 59,35 & 148,85 \\
\hline & & 2 & C. tagal & 21 & 700,00 & 42 & 37,50 & 35,07 & 114,57 \\
\hline & & 3 & B. gymnorrhiza & 3 & 100,00 & 6 & 25,00 & 5,56 & 36,56 \\
\hline & & & Total & 50 & 1666,66 & 100 & 100 & 100 & 300 \\
\hline & \multirow{4}{*}{ tiang } & 1 & R.apiculata & 49 & 1633,33 & 90,74 & 42,85 & 92,09 & 225,68 \\
\hline & & 2 & C. tagal & 4 & 133,33 & 7,40 & 42,85 & 6,54 & 56,80 \\
\hline & & 3 & R. Mucronata & 1 & 33,33 & 1,85 & 14,28 & 1,36 & 17,50 \\
\hline & & & Total & 54 & 1800,00 & 100 & 100 & 100 & 300 \\
\hline \multirow{7}{*}{ II } & \multirow{4}{*}{ Sapihan } & 1 & R.mucronata & 136 & 4533,33 & 88,31 & 33,33 & 85,77 & 207,41 \\
\hline & & 2 & B. gymnorrhiza & 13 & 433,33 & 8,44 & 33,33 & 9,60 & 51,38 \\
\hline & & 3 & R.apiculata & 5 & 166,66 & 3,24 & 33,33 & 4,62 & 41,20 \\
\hline & & & Total & 154 & 5133,33 & 100 & 100 & 100 & 300 \\
\hline & \multirow{3}{*}{ tiang } & 1 & R.mucronata & 1 & 33,33 & 20,00 & 33,33 & 27,70 & 81,04 \\
\hline & & 2 & R.apiculata & 4 & 133,33 & 80,00 & 66,66 & 72,29 & 218,95 \\
\hline & & & Total & 5 & 166,66 & 100 & 100 & 100 & 300 \\
\hline \multirow{5}{*}{ III } & \multirow{4}{*}{ Sapihan } & 1 & R.mucronata & 15 & 500,00 & 22,38 & 33,33 & 18,50 & 74,22 \\
\hline & & 2 & B. gymnorrhiza & 9 & 300,00 & 13,43 & 33,33 & 8,76 & 55,52 \\
\hline & & 3 & R.apiculata & 43 & 1433,33 & 64,17 & 33,33 & 72,73 & 170,24 \\
\hline & & & Total & 67 & 2233,33 & 100 & 100 & 100 & 300 \\
\hline & tiang & 1 & R.mucronata & 2 & 66,66 & 11,11 & 37,50 & 12,04 & 60,66 \\
\hline
\end{tabular}




\begin{tabular}{|c|c|c|c|c|c|c|c|c|c|}
\hline St & $\begin{array}{c}\text { Tingkatan } \\
\text { Vegetasi }\end{array}$ & No & Nama Spesies & $\sum_{\text {ind }}$ & K (ind/ha) & KR (\%) & FR $(\%)$ & DR & INP $(\%)$ \\
\hline & \multirow{6}{*}{ Pohon } & 2 & R.apiculata & 14 & 466,66 & 77,77 & 37,50 & 70,60 & 185,88 \\
\hline & & 3 & B. gymnorrhiza & 1 & 33,33 & 5,55 & 12,50 & 8,09 & 26,14 \\
\hline & & \multirow[t]{2}{*}{4} & S.alba & 1 & 33,33 & 5,55 & 12,50 & 9,25 & 27,30 \\
\hline & & & Total & 17 & 600,00 & 100 & 100 & 100 & 300 \\
\hline & & \multirow[t]{2}{*}{1} & S.alba & 7 & 233,33 & 100 & 100 & 100 & 300 \\
\hline & & & Total & 7 & 233,33 & 100 & 100 & 100 & 300 \\
\hline
\end{tabular}

Keterangan: $\sum$ indv = Jumlah Individu; K = Kerapatan; KR = Kerapatan Relatif; FR = Frekuensi Relatif; DR = Dominansi Relatif; INP= Indeks Nilai Penting

\section{b. Persentase Tutupan dengan Hemisperichal Photography}

Persentase tutupan mangrove ditentukan berdasarkan nilai pixel gambar kanopi ekosistem mangrove. Hasil gambar yang diperoleh kemudian dilakukan pemisahan nilai pixel langit. Hasil analisis perbandingan pixel langit dan pixel kanopi tersebut ditunjukkan pada Tabel 3.

\section{c. Biomassa Permukaan (AGB) dan Stok Karbon Vegetasi Mangrove}

Hasil analisis biomassa permukaan atas mangrove $(A G B)$ dan estimasi stok karbon vegetasi mangrove di setiap lokasi penelitian menunjukkan perbedaan biomassa maupun stok karbon tiap spesies mangrove dan tiap lokasi penelitian, ditunjukkan pada Tabel 4.

Tabel 3. Persentase tutupan mangrove

\begin{tabular}{|c|c|c|c|c|}
\hline Stasiun & $\begin{array}{c}\text { Strata } \\
\text { vegetasi }\end{array}$ & $\begin{array}{c}\text { Kerapatan Mangrove } \\
\left(\text { ind } / \mathbf{h a}^{2}\right)\end{array}$ & $\begin{array}{l}\text { Tutupan vegetasi } \\
\text { berbasis pixel }(\%)\end{array}$ & $\begin{array}{c}\text { Kategori berdasarkan Kepmen } \\
\text { LH NO. } 201 \text { tahun } 2004\end{array}$ \\
\hline \multirow{3}{*}{ St I } & Sapihan & 1666,66 & - & - \\
\hline & Tiang & 1800,00 & - & - \\
\hline & Total & 3466,66 & $81,5368 \pm 4,4182$ & Baik /padat \\
\hline & Sapihan & 5133,33 & - & - \\
\hline \multirow[t]{2}{*}{ St II } & Tiang & 166,66 & - & - \\
\hline & Total & 5299,99 & $84,0716 \pm 3,9071$ & Baik /padat \\
\hline \multirow{4}{*}{ St III } & Sapihan & 2233,33 & - & - \\
\hline & Tiang & 600,00 & - & - \\
\hline & Pohon & 233,33 & - & - \\
\hline & Total & 3066,66 & $80,9978 \pm 4,6604$ & Baik /padat \\
\hline
\end{tabular}

Keterangan: Kategori Baik (padat) jika penutupan $\geq 75 \%$ atau kerapatan $\geq 1500$ ind $/ \mathrm{ha}^{2}$; Sedang jika penutupan $50-75 \%$ atau kerapatan $1000-1500 \mathrm{ind} / \mathrm{ha}^{2}$; Rusak (jarang) jika penutupan $<50 \%$ atau kerapatan $<1000 \mathrm{ind} / \mathrm{ha}^{2}$. 
66 Hasidu et al.

JURNAL SAINS dan INOVASI PERIKANAN / Journal of Fishery Science and Innovation

Vol. 5, No. 2, 60-71, Juli 2021

Tabel 4. Biomassa permukaan dan stok karbon

\begin{tabular}{|c|c|c|c|}
\hline Lokasi & Spesies Mangrove & Biomassa (ton/ha) & Karbon (ton/ha) \\
\hline \multirow{5}{*}{ St 1} & R. apiculata & 201,3032 & 94,6125 \\
\hline & R. mucronata & 2,0848 & 0,9798 \\
\hline & C. tagal & 22,7997 & 10,7159 \\
\hline & B. gymnorrhiza & 0,9991 & 0,4696 \\
\hline & Total & 226,7638 & 106,5790 \\
\hline \multirow{4}{*}{ St 2} & R. apiculata & 15,3642 & 7,2211 \\
\hline & R. mucronata & 58,3265 & 27,4134 \\
\hline & B. gymnorrhiza & 4,0466 & 1,9019 \\
\hline & Total & 77,7373 & 36,5365 \\
\hline \multirow{5}{*}{ St 3} & R. apiculata & 84,0816 & 39,5183 \\
\hline & R. mucronata & 13,7001 & 6,4390 \\
\hline & S. alba & 98,3057 & 46,2036 \\
\hline & B. gymnorrhiza & 6,0834 & 2,8592 \\
\hline & Total & 202,171 & 95,0202 \\
\hline
\end{tabular}

\section{Pembahasan}

Struktur vegetasi mangrove di ekosistem mangrove Kecamatan Latambaga menunjukkan ukuran diameter batang yang berbeda di setiap stasiunnya (Gambar 2). Pada umumnya, kelas ukuran DBH yang ditemukan di semua lokasi, didominasi oleh mangrove dengan kategori sapihan dan tiang, sangat sedikit mangrove yang ditemukan dengan kategori pohon. Hal yang sama ditemukan oleh Analuddin et al. (2015), di luar kawasan TNRAW, dimana banyak ditemukan individu kategori sapihan dan tiang, serta hanya terdapat beberapa individu $R$. apiculata dan $C$. tagal dengan kategori pohon. Momo\& Rahayu (2018), menemukan jumlah individu mangrove tingkatan sapihan lebih banyak (220 individu), dibandingkan tingkatan pohon (128 individu), dan tiang (79 individu) di hutan mangrove Desa Wambona, Muna. Onrizal \& Kusmana (2008), menyatakan bahwa ekosistem mangrove dengan tingkat pertumbuhan sapihan dan tiang yang mendominasi mengindikasikan ekosistem mangrove tersebut dalam tahap perkembangan.

Kerapatan vegetasi mangrove di semua lokasi menunjukkan tingkat kerapatan kategori padat menurut kepmen LH No 201 tahun 2004 (K > 1500 ind/ ha ${ }^{2}$ ) (Tabel 2). Kerapatan vegetasi mangrove yang ditemukan di lokasi penelitian ini tidak lebih rapat jika dibandingkan dengan hasil yang diperoleh oleh Susiana \& Suhana (2019) yang menemukan kerapatan mangrove di Desa Berakit, Pulau Bintan berkisar antara $2.600 \mathrm{ind} / \mathrm{ha}^{2}$ sampai $9.900 \mathrm{ind} / \mathrm{ha}^{2}$, dikarenakan kondisi mangrove di lokasi tersebut masih dalam kondisi alami, dan belum terjadi kerusakan dan alih fungsi mangrove menjadi tambak seperti yang terjadi di ekosistem mangrove pesisir Kecamatan Latambaga. Rudia et al. (2019) memperoleh kerapatan mangrove yang jauh lebih rendah dari penelitian ini, yaitu berkisar 375- 1.600 ind/ha ${ }^{2}$ di Pulau Towea, Kabupaten Muna. Selain itu, Rizaldi et al. (2020) juga memperoleh kerapatan yang lebih rendah (993-1.397 ind/ha ${ }^{2}$ ) di kawasan Sei Jang, Kepulauan Riau. Rendahnya kerapatan di kedua lokasi tersebut dikarenakan telah terjadi degradasi dan alih fungsi mangrove dilokasi tersebut untuk beragam penggunaan laha. Selain itu, Rumalean et al., (2019) memperoleh kerapatan yang sedang (1.093 ind/ha ${ }^{2}$ ) di kawasan Taman Mangrove Mempawah yang disebabkan oleh pengaruh jarak tanam yang mempengaruhi pertumbuhannya yang kurang optimal.

Persentase tutupan mangrove menunjukkan bahwa persentase tutupan mangrove di semua lokasi masih dalam kategori tutupan mangrove yang padat. Padatnya tutupan mangrove di setiap stasiun sesuai dengan tingkat kerapatan vegetasinya (Tabel 3). Dari ketiga stasiun tersebut, ekosistem mangrove masih dikategorikan kondisi baik (padat) berdasarkan 
Kepmen-LH No 201 tahun 2004. Hasil yang diperoleh menunjukkan tutupan mangrove yang lebih tinggijika dibandingkan hasil yang diperoleh oleh Mauludin et al., (2018), dimana persentase tutupan yang diperoleh di Kawasan Ujung Piring Kabupaten Jepara pada kategori sedang. Hal ini dikarenakan kerapatan total tegakan mangrove yang diperoleh pada penelitian ini juga cukup tinggi, berkisar antara 3.066,66- 5.299,99ind/ha ${ }^{2}$, jauh lebih rapat dari yang ditemukan oleh Mauludin et al. (2018) dengan kerapatan total berkisar antara $1.500-2.433,33$ ind/ha ${ }^{2}$. Perbandingan data kerapatan dengan data tutupan mangrove berbasis pixel kanopi menunjukkan hasil yang berbanding lurus serta mengindikasikan tingkat akurasi data yang baik. Menurut Dharmawan \& Nontji (2017), penggunaan dengan metode hemisperichal photography memiliki hasil yang lebih akurat dalam menentukan persentase tutupan mangrove.

Berdasarkan hasil analisis kerapatan dan persentase tutupan di setiap stasiun, diperoleh bahwa di ketiga stasiun penelitian merupakan kawasan ekosistem mangrove yang masih padat (Tabel 3), meskipun di sekitar kawasan ekosistemnya terjadi degradasi dan alih fungsi lahan menjadi tambak, khususnya di stasiun 1 dan 2. Pernyataan ini didukung oleh Hasidu et al. (2020), yang menyatakan bahwa ekosistem mangrove di kabupaten kolaka sudah mengalami degradasi akibat adanya alih fungsi menjadi berbagai penggunaan lahan. Perubahan hutan mangrove primer menjadi kawasan bukan mangrove terjadi di stasiun 1 dan 2 tersebut. Hal ini terjadi karena konversi dan pembukaan kawasan mangrove menjadi kawasan budidaya perikanan. Namun, perubahan ekosistem mangrove primer menjadi kawasan mangrove sekunder tidak ditemukan di kedua lokasi tersebut. Menurut Onrizal (2010), perubahan kawasan mangrove primer menjadi kawasan mangrove sekunder terjadi karena adanya aktivitas penebangan hutan mangrove untuk berbagai keperluan, namun masih menyisahkan vegetasi mangrove. Sedangkan perubahan kawasan mangrove menjadi kawasan bukan mangrove terjadi karena adanya alih fungsi kawasan. Analuddin et al.
(2015) menemukan hal yang sama terjadi, dimana kawasan ekosistem mangrove di luar kawasan TNRAW, Sulawesi Tenggara mengalami degradasi akibat perubahan fungsi lahan menjadi tambak. Aktivitas alih fungsi kawasan mangrove juga menunjukkan hasil yang bervariatif dari aspek jenis penggunaan lahan sebagaimana yang diperoleh Hamuna \& Tanjung (2018) di Teluk Yuotefa, Kota Jayapura yang didominasi oleh faktor antropogenik berupa alih fungsi lahan dalam bentuk penebangan, pembangunan jalan, jembatan serta permukiman.

Biomassa suatu tumbuhan tersusun atas berbagai macam unsur seperti hidrogen, oksigen, dan didominasi oleh karbon (C) yang dihasilkan oleh proses fotosintesis dari tumbuhan tersebut (Suryono et al., 2018). Estimasi biomassa permukaan mangrove $(A G B)$ pada umumnya dilakukan dengan menggunakan data $D B H$ dan persamaan allometrik baik yang akan dikembangkan, maupun yang telah dikembangkan untuk spesies yang sama (Sutaryo, 2009). Hasil estimasi biomassa permukaan mangrove ditunjukkan pada Tabel 4. Berdasarkan data tersebut (Tabel 4), tingginya total $A G B$ yang ditemukan pada stasiun 1, disebabkan karena terdapat beberapa spesies mangrove dengan strata pertumbuhan tiang $(D B H>10 \mathrm{~cm})$ yang memiliki jumlah individu yang lebih banyak dari lokasi lain (tabel 1). Hal ini menyebabkan tingginya biomassa yang diperoleh sebagai hasil perhitungan antara $D B H$ dengan persamaan allometrik. Banyaknya jumlah individu dengan strata pertumbuhan sapihan $(D B H>10 \mathrm{~cm})$ di stasiun 2 dan 3 sedikit memberikan pengaruh terhadap penambahan nilai $A G B$, karena memiliki $D B H$ yang kecil dibandingkan tiang. Menurut Analuddin et al., (2016) tren AGB berhubungan dengan usia dan struktur tegakan, serta karakteristik habitat.

Hasil ini jauh lebih kecil jika dibandingkan dengan hasil yang diperoleh oleh Analuddin et al (2018) di kawasan TNRAW, yang memperoleh $A G B$ dengan kisaran 162,61 - 651,60 ton/ha. Hal ini dikarenakan kawasan ekosistem mangrove tersebut merupakan kawasan konservasi sehingga ekosistem mangrovenya masih dalam kondisi alami. Zulhalifah 
68 Hasidu et al.

JURNAL SAINS dan INOVASI PERIKANAN / Journal of Fishery Science and Innovation Vol. 5, No. 2, 60-71, Juli 2021

et al. (2021)memperoleh total biomasa 1.388,79 ton/ha.Tingginya biomassa tersebut kemungkinan dipengaruhi oleh jumlah individu setiap spesies yang diperoleh 475 individu lebih banyak dari jumlah individu semua spesies penelitian ini (337 individu).Sementara itu, Suryono et al (2018) memeperoleh hasil relatif lebih kecil $(A G B=187,21$ ton/ha) jika dibandingkan dengan hasil penelitian ini (Tabel 4). Hal ini disebabkan karena kerapatan mangrove yang ditemukan lebih rendah (berkisar antara $1.494-2.123 \mathrm{ind} / \mathrm{ha}^{2}$ ), jika dibandingkan dengan penelitian ini (kerapatan berkisar antara 3.066,66 - 5.299,99 ind/ha ${ }^{2}$ ). Tingkat kerapatan mangrove dapat menggambarkan seberapa banyak tegakan mangrove yang ada dalam suatu kawasan.

Jika ditinjau berdasarkan $A G B$ antar spesies, $R$. apiculata memiliki $A G B$ yang lebih tinggi dari spesies lain. Hal tersebut juga dipengaruhi oleh jumlah individu spesies $R$. apiculata dengan strata pertumbuhan tiang yang lebih banyak (49 individu) dibandingkan spesies lain (tabel 1). Selain itu, spesies S. alba juga memiliki $A G B$ yang cukup tinggi $(79,82$ ton/ha). Meskipun jumlah individu spesies $S$. alba yang relatif sedikit, tetapi spesies tersebut memiliki 7 individu dengan strata pertumbuhan pohon ( $D B H$ $>20 \mathrm{~cm}$ ). Hal tersebut menyebabkan hasil perhitungan antara $D B H$ dengan persamaan allometriknya menjadi lebih besar.Adanya perbedaan AGB kemungkinan disebabkan oleh adanya perbedaan kondisi lingkungan, komposisi spesies, karakteristik vegetasi, habitat tempat tumbuhnya, letak geografisnya, perbedaan iklim (Komiyama et al., 2008), strata dan usia pertumbuhan, maupun nutrient (Analuddin et al., 2016).

Mangrove berperanan penting dalam penyuplai $\mathrm{O}_{2}$, penyerap dan penyimpan $\mathrm{CO}_{2}$ (Analuddin et al., 2020) dan mampu menyimpan karbon dengan jumlah yang banyak (Alongi \& Mukophadhyay, 2015; Adame et al., 2017). Simpanan karbon dalam suatu vegetasi mangrove menggambarkan seberapa besar kapasitas vegetasi mangrove tersebut dalam menyerap dan menyimpan karbon dalam bentuk biomassa vegetasi. Besarnya biomassa vegetasi, dan ukuran pohon diprediksi mempengaruhi kapasitas simpanan karbonnya (Analuddin et al., 2020). Berdasarkan hasil penelitian yang diperoleh (Tabel 4),stok karbon tertinggi pada stasiun 1 sebesar 106,57 ton/ha, diikuti oleh stasiun 3 sebesar 85,29 ton/ha, dan stasiun 2 sebesar 35,75 ton/ha. Tingginya stok karbon yang ada pada stasiun 1 berbanding lurus dengan tingginya $A G B$ di lokasi tersebut. Jika ditinjau berdasarkan stok karbonantar spesies, $R$. apiculata memiliki stok karbonyang lebih tinggi dari spesies lain. Hal tersebut juga dipengaruhi oleh nilai $A G B$ spesies $R$. apiculata yang juga lebih tinggi jika dibandingkan dengan spesies lain. Selain itu, spesies $S$. alba di stasiun 3 dan $R$. mucronata di stasiun 2 juga memiliki stok karbonyang cukup tinggi, yaitu sebesar 37,51 ton/ha, dan 27,41 ton/ha secara berturut-turut. Stok karbon kedua spesies tersebut dipengaruhi oleh $A G B$ yang cukup tinggi. Secara keseluruhan, total stok karbon ini masih relatif rendah jika dibandingkan total stok karbon yang diperoleh oleh Analuddin et al., (2020), sebanyak 264,50 ton/ha. Hal tersebut dipengaruhi oleh status kawasan di lokasi penelitiannya termasuk dalam kawasan konservasi TNRAW yang terlindungi dan masih alami, sedangkan kawasan mangrove pesisir Kabupaten Kolaka bukan merupakan kawasan konservasi. Hal tersebut didukung oleh Kusumaningtyas et al. (2019), yang memperoleh stok karbon yang lebih tinggi di kawasan mangrove Pulau Kongsi dan Berau yang masih alami, dibandingkan di Laguna Segara Anakan yang mengalami degradasi.Total stok karbon yang ditemukan di lokasi penelitian ini, juga memiliki hasil bervariatif jika dibandingkan dengan hasil yang diperoleh oleh Rahman et al. (2017) yang menemukan stok karbon mangrove di Sungai Tallo, Makassaryang didominasi oleh spesies N. Fruticans dengan jumlah pohon 18.514 pohon memiliki cadangan karbon 21,82 ton/ha, sedangkan spesies $R$. mucronata memiliki cadangan karbon 19,94 ton/ha yang tersimpan pada 8.492 pohon, serta A. Alba menyimpan karbon sebesar 53,96 ton/ha dengan total jumlah pohon pada spesies ini sebanyak 2.421 pohon.

Berkurangnya kawasan ekosistem mangrove sangat berdampak terhadap keseimbangan ekosistem. Ekosistem ini memiliki peranan bagi masyarakat 
(Rumalean \& Purwanti, 2019), sebagai penyerap emisi $\mathrm{CO}_{2}$ di atmosfer (Analuddin et al., 2020), penyerap pencemaran logam berat (Hasidu et al., 2015).

\section{KESIMPULAN}

Berdasarkan hasil penelitian yang diperoleh maka dapat disimpulkan bahwa kondisi vegetasi berdasarkan kerapatan dan persentase tutupan kanopi mangrove di Kecamatan Latambaga, masih dalam kondisi yang baik dan didominasi oleh mangrove strata pertumbuhan sapihan hingga tiang. Kerapatan mangrove yang diperoleh berkisar antara 3.066,66 ind/ha ${ }^{2}$ hingga $5.299,99$ ind/ $\mathrm{ha}^{2}$, dan masih dikategorikan dalam kondisi kerapatan yang tinggi. Sementara itu, persentase penutupannya mangrove yang diperoleh berkisar antara 80,9978\% hingga $84,0716 \%$, juga masih dikategorikan dalam tutupan yang baik (tutupan > 75\%). Status biomasa permukaan $(A G B)$ yang diperoleh berkisar antara 76,06 ton/ha hingga 226,76 ton/ha.Vegetasi mangrove di pesisir Kecamatan Latambaga memiliki potensi sebagai penyerap dan menyimpan karbon dalam bentuk biomassanya. Total stok karbon yang tersimpan dalam vegetasi mangrove berkisar antara 35,75 ton/ha hingga 106,57 ton/ha. Meskipun demikian, kawasan di sekitar ekosistem mangrove sudah mengalami alih fungsi menjadi tambak. Diperlukan upaya pengelolaan kawasan ekosistem untuk mendukung fungsi ekosistem mangrove tersebut sebagai peneyrap dan penyimpan karbon, kaitannya dengan fungsi ekosistem mangrove dalam memitigasi dampak perubahan iklim.

\section{Ucapan Terima Kasih}

Ucapan terima kasih kepada kepala LPPM USN Kolaka yang telah memberikan izin untuk melakukan penelitian nomor 017/UN56D/LT/2020, serta Pemkab Kolaka atas izin pelaksanaan penelitian. Terimakasih kepada saudara Dandy Afriansyah dan WEBCare yang turut membantu dalam proses pengambilan data di lapangan.

\section{DAFTAR PUSTAKA}

Adame MF, Cherian S, Reef R,and Stewart-Koster, B. 2017. Mangrove root biomass and the uncertainty of belowground carbon estimations. Forest Ecology and Management, 403, 52-60. https://doi.org/10.1016/j.foreco.2017.08.016

Aksornkoae. 1993. Ecology Management of Mangroves. Ecology Management of Mangroves.IUCN Wetlands Programe, IUCN. Bangkok.

Alongi DM, and Mukhopadhyay SK. 2014. Contribution of mangroves to coastal carbon cycling in lowlatitude seas. Agricultural and Forest Meteorology xxx (2014) $\mathrm{xxx}-\mathrm{xxx}$. http://dx.doi.org/10.1016/j.agrformet.2014.10.00 5

Alongi DM, and Mukophadhyay SK. 2015. Contribution of mangroves to coastal carbon cycling in lowlatitude seas.pdf. Agric. Forest Meteorol. http://dx.doi.org/10.1016/j.agrformet.2014.10.00 5.

Analuddin K, Jamili, Septiana A, Raya R, Sahidin I, Rianse U, Rahim S, Alfirman, Sharma S, and Nadaoka K. 2016b. Allometric models and aboveground biomass of Lumnitzeraracemosa Willd. forest in Rawa Aopa Watumohai National Park, Southeast Sulawesi, Indonesia, Forest Science and Technology, 12:1, 43-50, https://doi.org/10.1080/21580103.2015.1034191

Analuddin K, Jamili, Septiana A, Izal, Fajar, LOA, Raya R, Sahidin I, Rianse U, Rahim S, Alfirman, and Nadaoka K. 2015. Aboveground biomass status and management effort of unprotected mangrove forest at the surrounding areas of Rawa Aopa Watumohai National Park, Indonesia. Advances in Environmental and Geological Science and Engineering. (pp. 393400).

Analuddin K, Kadidae LO, Haya LOM, Septiana A, Sahidin I, Syahrir L, Rahim S, Fajar LOA, and Nadaoka K. 2020. Aboveground biomass, productivity and carbon sequestration in Rhizophora stylosa mangrove forest of Southeast Sulawesi, Indonesia. BIODIVERSITAS, 21(4). https://doi.org/10.13057/biodiv/d210407

Analuddin K, Sharma S, Jamili, Septiana A, Sahidin I, Rianse U, Rahim S, and Nadaoka K. 2018. Trends in allometric models and aboveground biomass of family Rhizophoraceae mangroves in 
70 Hasidu et al.

JURNAL SAINS dan INOVASI PERIKANAN / Journal of Fishery Science and Innovation Vol. 5, No. 2, 60-71, Juli 2021

the Coral Triangle ecoregion, Southeast Sulawesi, Indonesia. Journal of Sustainable Forestry, 37(7), 691-711. https://doi.org/10.1080/10549811.2018.1453843

Analuddin K, Sharma S, Jamili, Septiana A, Sahidin, I, Rianse U, and Nadaoka K. 2017. Heavy metal bioaccumulation in mangrove ecosystem at the coral triangle ecoregion, Southeast Sulawesi, Indonesia. Marine Pollution Bulletin. http://dx.doi.org/10.1016/j.marpolbul.2017.07.06 5.

Clough BF, and Scott K. 1989. Allometric relationship for estimating above-ground biomass in six mangrove species. Forest and Management. 27 (1989), 117-127.

Dharmawan IWE, and Nontji A. 2017. Panduan monitoring status ekosistem mangrove. (edisi 2). COREMAP-CTI LIPI.Jakarta.

Hamuna B, dan Tanjung RH. 2018. Deteksi Perubahan Luasan Mangrove Teluk Youtefa Kota Jayapura Menggunakan Citra Landsat Multitemporal. Majalah Geografi Indonesia, 32(2), pp.151-122.

Hasidu LOAF, Jamili, Kharisma GN, Prasetya A, Maharani, Riska, Rudia LOAP, Ibrahim AF, Mubarak AA, Muhsafaat LO, and Anzani L. 2020. Diversity of mollusks (bivalves and gastropods) in degraded mangrove ecosystems of Kolaka district, Southeast Sulawesi, Indonesia. Biodiversitas.(21) 12, December 2020. DOI: 10.13057/biodiv/d211253.

Hasidu LOAF, Septiana A, and Analuddin K. 2015. Heavy Metals Bioaccumulation in Mangroves Rhizophoraceae at the Rawa Aopa Watumohai National Park (RAWNP). Proceeding of celebes international conference on diversity at wallacea's line (pp. 380-386). Kendari.

Hatchings P,and Saenger P. 1987. Ecology of mangroves. University of Queensland press.St Lucia. London. Newyork.

Indrayani E, Kalor JD, Warpur M, and Hamuna B. 2021. Using allometric equations to estimate mangrove biomass and carbon stock in Demta Bay, Papua Province, Indonesia. Journal of Ecological Engineering. 2021, 22(5), 263-271 https://doi.org/10.12911/22998993/135945

Jamili, Setiadi D, Qayim I, dan Guhardja E. 2009. Struktur dan Komposisi Mangrove di Pulau Kaledupa Taman Nasional Wakatobi, Sulawesi Tenggara. Ilmu Kelautan 14 (4). 197-206.
Jamili. 2019. Flora Mangrove Taman Nasional Wakatobi. Penerbit Universitas Halu Oleo Press. Kendari.

Kauffman JB, Heider C, Norfolk J, and Payton F. 2014. Carbon stocks of intact mangroves and carbon emissions arising from their conversion in the Dominican Republic. Ecological Applications, 24(3), 2014, pp. 518-527.

Keputusan Menteri LH tahun 2004. Surat Keputusan Menteri Negara Lingkungan Hidup No 201 Tentang Kriteria Baku Dan Pedoman PenentuanKerusakan Mangrove. No. 201, Indonesia.

Komiyama A, OngJE, and Poungparn S. 2008. Allometry, biomass and productivity of mangrove forest: a review. Aquatic Botany. 89 (2008).

128-137. doi:10.1016/j.aquabot.2007.12.006

Kusmana C, Hidayat T, Tiryana T, Rusdiana O, and Istomo. 2018. Allometric models for above- and below-ground biomass of Sonneratia spp. Global Ecology and Conservation 15 (2018) e00417. https://doi.org/10.1016/j.gecco.2018.e00417

Kusmana C. 1993. Study of Mangrove Forest Management based on Ecologycal Data in East Sumatera, Indonesia. Japan. Kyoto University.

Kusumaningtyas MA, Hutahaean AA, Fischer HW, Pérez-Mayo M, Ransby D, and Jennerjahn TC. 2019. Variability in the organic carbon stocks, sources, and accumulation rates of Indonesian mangrove ecosystems. Estuarine, Coastal and Shelf Science, 218, 310-323. https://doi.org/10.1016/j.ecss.2018.12.007.

Mauludin MR, Azizah R, Pribadi R, dan Suryono. 2018. Komposisi dan Tutupan Kanopi Mangrove di Kawasan Ujung Piring Kabupaten Jepara. Buletin Oseanografi Marina. April 2018 Vol 7 No 1:29-36. EISSN : 2550-0015

Momo LOH, dan Rahayu WOS. 2018. Analysis of mangrove forest vegetation in Wambona Village, South Wakorumba District, Muna Regency, Indonesia. Akuatikisle: Jurnal Akuakultur, Pesisir dan Pulau-Pulau Kecil, 2(1), 10. https://doi.org/10.29239/j.akuatikisle.2.1.10-16

Murniati DC, dan Pratiwi R. 2015. Kepiting uca di hutan mangrove Indonesia: Tinjauan aspek biologi dan ekologi untuk eksplorasi (Cetakan pertama). LIPI Press.Menteng, Jakarta.

Noor YR, Khazali M,dan Suryadiputra INN. 2006. Panduan pengenalan mangrove di Indonesia. 
Ditjen PHKA : Wetlands International, Indonesia Programme. Bogor.

Nybakken JW. 1992. Biology Laut (Suatu Pendekatan Ekologis). Diterjemahkan oleh Eigman. Gramedia. Jakarta.

Onrizal, dan Kusmana. 2008. Studi Ekologi Hutan Mangrove di Pantai Timur Sumatera Utara. $\begin{array}{llll}\text { Biodiversitas. } & 9 & \text { (1), } & \text { 25-29. }\end{array}$ doi.10.13057/biodiv/d090107.

Onrizal. 2010. Perubahan Tutupan Hutan Mangrove di Pantai Timur Sumatera Utara Periode 1977 2006. J.Biol. Indon 6 (2), 163-172.

Profil Kawasan Konservasi Provinsi Sulawesi Tenggara Tahun 2015. Direktorat Konservasi Kawasan dan Jenis Ikan, Direktorat Jendral Kelautan, Pesisir dan Pulau-Pulau Kecil, Kementerian Kelautan dan Perikannan.http://kkji.kp3k.kkp.go.id

Rahman R, Efendi H, dan Rusmana I. 2017. Estimasi Stok dan Serapan Mangrove di Sungai Tallo, Makassar. Jurnal Ilmu Kehutanan, 11(1), pp.1928.

Rizaldi H, Lestari F, dan Susiana. 2020. Tingkat kerusakan ekosistem mangrove di Kawasan Estuari Sei JangKecamatan Bukit Bestari Kota Tanjungpinang, Kepulauan Riau,Indonesia. Akuatikisle: Jurnal Akuakultur, Pesisir dan Pulau-Pulau Kecil. Vol. 4 No. 2: 47. 51November 2020. EISSN 2598-8298. DOI: https://doi.org/10.29239/j.akuatikisle.4.2.47-51

Rudia LOAP, Bahtiar B, Jamili J, Muhsin M, dan Nasaruddin N. 2019. Diversitas Gastropoda Berdasarkan Tingkat Kerusakan Mangrove Di Pulau Towea Kabupaten Muna Sulawesi Tenggara. BioWallacea: Jurnal Penelitian Biologi (Journal of Biological Research), 6 (1). DOI: 10.33772/biowallacea.v6i1.8742

Rumalean AS, dan Purwanti F. 2019. Struktur komunitas hutan mangrove pada kawasan mempawah mangrove park di desa pasir mempawah hilir. Jurnal Ilmu dan Teknologi Kelautan Tropis, 11(1), 221. https://doi.org/10.29244/jitkt.v11i1.25704

Sharma S, MacKenzie RA, Tieng $T$, Soben K, Tulyasuwan N, Resanond A, Blate G, and Litton CM. 2019. The impacts of degradation, deforestation and restoration on mangrove ecosystem carbon stocks across Cambodia. Science of the Total Environment (2019), doi: https://doi.org/10.1016/j.scitotenv.2019.135416
Suryono, Soenardjo N, Wibowo E, Ario R dan Rozy FF. 2018. Estimasi Kandungan Biomassa dan Karbon di Hutan Mangrove Perancak Kabupaten Jembrana, Provinsi Bali. Buletin Oseanografi Marina, Vol 7, No 1. EISSN: 2550-0015.

Susiana Sand Suhana MP. 2019. Mangrove damage level in the waters of Berakit Village, Bintan Island, Indonesia. Akuatikisle: Jurnal Akuakultur, Pesisir dan Pulau-Pulau Kecil, 3(2), 73. https://doi.org/10.29239/j.akuatikisle.3.2.7379

Sutaryo D. 2009. Penghitungan biomassa: Sebuah pengantar untuk studi karbon dan perdagangan karbon. Wetlands International Indonesai Programme. Bogor, Indonesia.

Zulhalifah, Syukur A, Santoso D, and Karnan. 2021. Species diversity and composition, and aboveground carbon of mangrove vegetation in Jor Bay, East Lombok, Indonesia. Biodiversitas 22 (4): 2066-2071, April 2021. DOI: 10.13057/biodiv/d220455 